\title{
Slavery and the Cotton Boom
}

\author{
GAVIN WRIGHT \\ University of Michigan
}

From the cotton gin until World War II, the pace of economic expansion in the American South was principally governed by the rate of growth of world cotton demand. From this perspective, many features of the antebellum Southern economy described in Time on the Cross (Fogel and Engerman, 1974, Vols. I, II) need not be viewed as characteristics of slavery as a system of production. The profitability and apparent efficiency of slave labor, the high regional growth rates, and the sanguinity of slaveowners all rested on an inherently impermanent foundation: the extraordinary growth of world demand for cotton between 1820 and 1860 . As the demand for cotton collapsed and then stagnated between 1860 and 1900, the economic successes of slavery would not have persisted. In particular, slave prices would have declined, the growth rate of regional income would have been drastically reduced, and much of the superior measured "efficiency" of slave labor would have evaporated.

\section{Cotton Demand and the Profitability of Slavery}

In Chapter 3 of Time on the Cross, Fogel and Engerman establish that the 1850's were a period of enormous profits for slaveholding cotton planters, and that the demand for cotton grew rapidly to the very end of the decade (I, pp. 89-94). Much of the actual profitability was realized in the form of capital gains-an increase in the value of slaves - a fact which supports the further proposition that the expectations of slaveowners were highly optimistic at the time of secession (I, pp. 103-106). What is not established is that these expectations were justified by the prospective economic future, nor that the growth of cotton demand would have continued.

In fact, world cotton demand collapsed catastrophically in the 1860 's, a collapse everlastingly obscured by the virtually simultaneous disappearance of the American supply. Demand grew at approximately $5 \%$ per year from 1830 to 1860 ; between 1866 and 1895 the rate was less than $1.5 \%$. The impending downturn in the British textiles industry in the early 1860's has been widely noted; demand had barely recovered to its 1860 peak by the late 1870 's. Measured from the peak year, demand growth was little more than $1 \%$ per year to the turn of the century. ${ }^{1}$

The relatively high cotton prices of $1865-1880$ do not indicate strong de-

${ }^{1}$ These and other assertions in this section are documented in Wright, 1974. 
mand, but reflect instead the problems of the postbellum South in restoring cotton production to former levels. These postslavery production problems were certainly real, ${ }^{2}$ but the course of demand is in a sense a more basic cause for the slow recovery of Southern incomes: a faster growth of Southern cotton output would only have depressed the price that much faster. This stagnation in demand would have constituted a serious economic shock to the slaveowning class, had there been no war and no emancipation. This is not to say that slavery would have become "unprofitable" in any fundamental sense, only that the high profits, high slave prices, and high hopes of 1860 could not have persisted. As Ulrich Phillips wrote, "What shape [the] downward slope would have taken had peace continued it is idle to conjecture. But that a crash must have come is beyond a reasonable doubt." 3

The only point at which Fogel and Engerman address the question of post-1860 cotton demand is in the section of Chapter 3 in which they project slave prices, in the absence of a Civil War, to 1890 (I, pp. 95-97). They find that slave prices would have risen at approximately $1.4 \%$ per year. This result rests on "two solid facts": (1) that "demand for American cotton grew a little more rapidly than the supply... Hence the real price of cotton was higher in 1890 than in 1860 "; and (2) that "land devoted to cotton nearly doubled between 1860 and 1890" (I, pp. 96-97).

How can we reconcile these results with the evidence on world cotton demand? A growth rate of $1.4 \%$ per year is, of course, well below the pre- 1860 figure, and does provide evidence of slowing down. But even this much projected growth in slave prices is indefensible: it is not based on projected experience at all, but on the actual postwar (1890) levels of cotton production, prices, nonwhite population, and interest rates. It is difficult to believe that all these variables would have been the same under a post-1860 slave regime. The actual cotton production figures, for example, are far below any reasonable extrapolation of antebellum supply: hence cotton prices would surely have been lower than they actually were. And considering the high mortality of the war years and the lower black life expectancy thereafter, the 1890 slave population would surely (in the absence of a Civil War) have been greater than the actual 1890 nonwhite population. ${ }^{4}$

But even using the postbellum figures on supply, price, and population, the rise in the real value of cotton output to 1890 is too small to make any significant contribution to the projected slave price increase. Almost all of

${ }^{2}$ Ransom and Sutch, 1975.

${ }^{3}$ Phillips, 1918, p. 375.

${ }^{4}$ Ransom and Sutch (1975) attribute the fall in production primarily to the withdrawal of labor by the freedmen. The evidence on mortality during and after the war is discussed by Ransom and Sutch and by Edward Meeker "Mortality Trends of Southern Blacks 1850-1910: Some Preliminary Findings" Explorations in Economic History (forthcoming 1976). 
the increase in the Fogel-Engerman projection is attributable to a third "fact," which is not quite so solid: the fall in interest rates between 1860 and 1890 at a rate of about $2 \%$ per year. To believe this result, in other words, we have to take very seriously the interpretation of the railroad bond rate as the real opportunity cost of Southern capital for Southern farmers. Even if we ignore the large regional and local interest rate differentials which persisted in the nineteenth century, we can hardly ignore the 25 -year deflation in the general price level: at least some part of the decline in interest rates might reasonably be attributed to deflationary expectations rather than a real fall in the marginal productivity of capital. One scholar has recently argued that in real terms interest rates sharply rose between 1845-1861 and $1867-1878 .{ }^{5}$ Adjusting only the 1890 interest rate for the rate of deflation of the 1880 's would cut the rate of decline in the real interest rate in half.

The one component of the projection which might reasonably be assumed independent of the Civil War and its aftermath is cotton demand. But 1890 is not exactly a representative year for computing demand change. Estimates of the postbellum cotton demand curve indicate that the census year 1890 is in fact the most unrepresentative year available. ${ }^{6}$ Specifically, the percentage demand residual (actual minus "predicted" price) is higher for 1890 than for any other year in the estimating period (1866-1895). This untypicality is not quite evident in the chart on page 97 of Time on the Cross (Vol. I). The reader can see that most of the projected price increase comes after 1886, but he is not able to see that a sharp decline is in the offing for the 1890's.

By combining the Fogel-Engerman formula with reasonable projected rates of change for output and prices, and adjusting the interest rate for deflationary expectations, it is not difficult to generate projections of a slave price decrease of more than $1 \%$ per year for periods of $20-40$ years. Such projections are highly sensitive to assumptions and deserve skepticism. But since all of this discussion concerns changes in equilibrium slave prices, it is not implausible to assert that the plunge of slave prices during the cotton market collapse of the 1860's would have been very drastic indeed, in the light of the established pattern of overadjustment of slave prices in both upward and downward directions (I, p. 104). Ramsdell was on strong ground in forecasting an era of low cotton prices and falling slave values in the 1860 's and 1870's. Of course, there had been a major slave price fall earlier, but in contrast with the 1840's, the slaveholders of 1860 would have had to wait more than a generation to see their capital loss fully restored. Even if one is not willing to agree with Ramsdell that slavery would have died out

${ }^{5}$ Williamson, 1974, pp. 109-110. On regional interest-rate differentials, see Davis, 1965.

${ }^{8}$ The estimates are reported in Wright, 1974. p. 629. 
peacefully under this pressure, it is not going too far to say that the political and economic equilibrium of 1860 would have been severely disturbed.

\section{Was Slave Agriculture More Efficient than Free?}

Time on the Cross advances two types of propositions in connection with the productive efficiency of slavery (I, pp. 191-209): (1) that "southern slave agriculture" was $35 \%$ more efficient than "the northern system of family farming"; (2) that southern slave farms were $28 \%$ more efficient than small slave farms. These results are obtained, in both cases, by the calculation of a "geometric index of total factor productivity": the ratio of the value of output (at market prices) to an index of inputs of labor, capital, and land.

All intereconomy comparisons of aggregate efficiency are fraught with practical and conceptual difficulties, and many economists view them with great skepticism. The North-South indices of Time on the Cross, in particular, are quite sensitive to the assumed commodity prices and factor weights. Since prices and factor shares were quite different in the North and in the South, any proffered measure of relative efficiency is bound to be somewhat arbitrary. Among the debatable procedures employed, however, the most significant for the calculation is the use of land values (rather than acreage) to reflect differences in soil quality. This alteration accounts for most of the large efficiency advantage enjoyed by the South under the "refined" (as opposed to the "crude") index (II, pp. 131-138). The use of land values is dubious because it imparts a conceptual circularity to the whole exercise: economic theory suggests that any neutral regional difference in efficiency will be capitalized in the price of land, perhaps the more so in the North, where labor was not also capitalized. Further, land prices are affected by locational influences such as proximity to cities and access to transportation, influences which are not part of "output" as measured by Fogel and Engerman, and which tend to bias the ratio against the North. Some correction of the acreage total may be called for to reflect the higher fraction of improved land in the North; but even taking the extreme step of excluding all unimproved acreage does not yield nearly a $35 \%$ efficiency advantage for the South.

Cotton demand and supply also have an important role to play in the efficiency calculation. David and Temin make the essential theoretical point that one cannot define "productive efficiency" in a meaningful way where the production of one commodity is entirely limited for reasons of geography to one of the regions involved. ${ }^{7}$ It is true that in principle this difficulty afflicts all international comparisons of production. But for diversified industrial economies, one might be willing to suspend one's disbelief sufficiently to imagine a kind of generalized jelly called "output," which can be compared among countries. This conception is not very

'David and Temin, 1974, pp. 774-778. 
persuasive when a major component of "output" is a regionally distinct primary product. Hence, as David and Temin maintain, the regional index of total-factor productivity is not a meaningful basis for drawing inferences about the relative hardworkingness of slave and free labor, nor the relative efficiencies of the "plantation-slavery system" and the "family-farm system."

Putting aside the empirical objections, however, one may still view these indices as generalized measures of the extraordinary economic success of the slave economy in the census year 1859-1860. But even if we adopt this less-far-reaching interpretation, it is relevant to take note of just how unusual and unrepresentative the census year 1859-1860 was. Econometric estimates of the cotton demand curve indicate that the actual cotton price for the crop year $1859-1860$ was between $7.6 \%$ and $15.9 \%$ above the level "predicted" by the function. ${ }^{8}$ This is another way of saying that demand was unusually high in that year. Bear in mind that this "residual" is from a demand curve which includes a trend of approximately $5 \%$ per year. The corresponding residual for supply ranges from $11.6 \%$ to $23.6 \%$, depending on the specification of the supply curve, on top of an annual growth rate of almost $6 \%$ per year. ${ }^{9}$

In the light of both the trends and the upward deviation from the trends, in short, there is no other year which would put the South in a better light in terms of the Fogel-Engerman version of "efficiency." Note that this is not the same as saying that the cotton price was exceptionally high, historically speaking. Because both supply and demand shifted dramatically, the price was only slightly above average. But that does not mean that the crop year was an ordinary one in the relevant sense. Its extraordinary character may be seen graphically in the sharp peaks in both supply and demand (I, Fig. 28, p. 92) in 1860. It is just this peak year which provides the one observation for comparison of total-factor productivity between regions.

Production estimates for Northern crops are not available on an annual basis, but the annual data which are available show plainly that neither supply nor demand conditions for the North during 1859-1860 were in any way comparable to those in the South. Far from being above the trend, exports of wheat, flour, and corn were well below both previous and subsequent levels in absolute terms. ${ }^{10}$ Figures on internal shipments show no unusual level of activity for the census year. ${ }^{11}$ Northern farm prices were no better than "moderate" compared to the average for the 1850 's, though they were

${ }^{8}$ Wright, 1974, p. 629.

${ }^{9}$ The aggregate cotton supply curves may be found in Wright, 1969.

${ }^{10}$ See U.S. Census, 1860, pp. cxi-cxii.

"See, for example, Berry, 1943, pp. 168, 172; U.S. Census, 1860, pp. cxliv-clii; North, 1961, pp. 251-254. The census year production is presumably reflected primarily in the 1859 annual figures, which are particularly low. 
higher than in earlier census years. In any case it is not safe to take national price averages as indicators of the state of demand for northern crops. Compared to cotton, prices of food crops varied much more widely among major markets, increasingly so in 1859-1860. On the general prosperity of Western agriculture, Berry refers to the period 1860-1861 as a "low-water mark" (p. 530). One of the best general indicators of agricultural prosperity is the value of public land sales, which stood at a peak for the South in 1859, while the Northwest approached a trough. ${ }^{12}$

It is the deviation of demand from its trend which chiefly affects the aggregate regional efficiency index. Because of the dominance of world cotton markets by American cotton, short-run fluctuations in supply were generally accompanied by roughly proportional inverse changes in price; the enormous census year crop would have depressed the price, had it not been for the unusually strong demand. In a situation where the demand elasticity is close to unity, it is only demand that can expand the aggregate value of cotton production. Comparisons within the South are also affected by cotton demand-obviously so, since it is only in the great staple crops that Fogel and Engerman claim to have found a productivity advantage to slave labor-but here supply-side fluctuations may be more crucial. In the context of high demand, much of the intra-South pattern of "efficiency" can be explained by the deviation of supply from its trend.

The bumper crop of the census year was especially good in the "New South." A cotton supply curve estimated for the leading New South cotton states only (but excluding Texas) shows a spectacular 40-year average annual growth rate of $7 \%$ per year. ${ }^{13}$ Even from this supply curve, the census year $1859-1860$ shows a positive residual between $35.2 \%$ and $43.5 \%$. Small wonder that Fogel and Engerman find a substantial "total-factor-productivity" advantage for the New over the Old South (I, pp. 194-196; II, pp. 138-140). Other reviewers have commented on how un reasonable it would be to infer that New South slaves worked harder than Old South slaves. ${ }^{14}$ Attention to the peculiarities of the census year resolves this problem, but it casts further doubt on the wisdom of drawing such inferences in general.

The exceptional cotton crop of $1859-1860$ is also crucial for the comparison of farms and plantations of various sizes within the South. The "total-factor-productivity" indices do not compare productivity in cotton,

\footnotetext{
${ }^{12}$ North, 1961, p. 256. Berry (1943) notes the increasing price divergence among major markets in 1859 and 1860 (p. 528). It is true that Berry's series on "Western States Terms of Trade" shows a peak in 1859 (North, 1961, p. 255), but these high prices prevailed for the first half of the year only (Berry, 1943, p. 505) and did not apply to the census year crop.

${ }^{13}$ The five-state supply curve is reported in Wright, 1971. The main states are Alabama, Arkansas, Louisiana, and Mississippi. Unfortunately, since the states were grouped for the purpose of using land-sales data, the series also includes Florida cotton production, but this is a trivial share of the total.

${ }^{14}$ Lichtman, 1974, p. 24.
} 
TABLE ।

Value of Cotton/(Value of Cotton + Value of Corn)

\begin{tabular}{lcccc}
\hline & \multicolumn{4}{c}{ Slaves per farm } \\
\cline { 2 - 5 } Region & 0 & $1-15$ & $16-50$ & 51 and over \\
\hline Cotton South & 0.300 & 0.401 & 0.556 & 0.661 \\
Old South & 0.269 & 0.373 & 0.492 & 0.605 \\
New South & 0.312 & 0.422 & 0.599 & 0.698 \\
\hline
\end{tabular}

Source: Parker-Gallman sample, 1860. The figures are unweighted averages of the farm ratios in each class. Cotton is valued at 104 per pound, corn at $80 \%$ per bushel.

but in the total value of output, where the composition of output varies systematically among farms. Small free Southern farms were not geographically debarred from cotton growing, but in fact they did specialize much more in noncotton crops and in livestock than the large plantations. This contrast may be illustrated crudely by measuring the share of cotton output in the cotton-corn total, for the size and regional groupings used by Fogel and Engerman (Table 1).

An investigation of patterns of labor productivity (using the same 1860 sample) yields three suggestive results: ${ }^{15}$ (a) the value of output per worker in 1860 is dominated by the share of cotton in total output; (b) when the crop mix is held constant, there is no productivity advantage for slave labor, and there are no scale economies for slave plantations; (c) if we assume that there were no true differences in labor productivity, the crop mix effect alone can generate a pseudoefficiency index very similar to the FogelEngerman total-factor-productivity figures. ${ }^{16}$ The Fogel-Engerman "efficiency" index thus appears to be largely a measure of who happened to be growing cotton during the most extraordinary cotton year of the ninetecnth century.

The application of the Fogel-Engerman procedure to earlier antebellum years would produce a reduced measure of the "efficiency advantage" of slavery, but quite possibly this measured advantage would not be completely eliminated. Hence, the question arises, Why did small and slaveless farms grow so much corn, when cotton apparently offered higher returns?

\footnotetext{
${ }^{15}$ These conclusions are based on linear regressions of the log of output value on the cotton share in output, and an index of soil quality. The "pseudoefficiency index" was generated by assuming that the coefficient of the cotton share was 1.0 , i.e., that a one-percentage-point rise in the cotton share produced a $1 \%$ rise in the value of output per worker. This is roughly the value indicated by the regressions. Obviously, the labor productivity evidence does not constitute a replication of the total-factor-productivity results, but the two will be proportional, ceteris paribus, under the Cobb-Douglas specification.

${ }^{16}$ The only instance where the crop-mix effect is not in the same direction as the FogelEngerman efficiency index is the case of farms with more than 50 slaves in the New South. Ironically, this is the one case where Fogel and Engerman believe that measurement error has contaminated their results (II, pp. 140-141). They suggest that a corrected set of results would show this to be the most efficient class.
} 
A major part of the answer lies in the fact that corn and hogs were produced for household consumption, while cotton was grown for the market. Small farmers, with low reserves and uncertain ability to borrow, were reluctant to commit themselves unduly to cash-crop production, following instead the popular advice: Achieve self-sufficiency in food first, grow cotton as a "surplus" crop. Such a "safety-first" strategy implies, under reasonable assumptions, that small farms will have to allocate a larger share of their acreage and time to nonmarket production, even if large plantations also typically strive for self-sufficiency. The basic underlying motivation is the desire to stay out of debt and protect the security of the family's sustenance and property. It is a reasonable strategy economically because-when one takes into account the combined risks of cotton yields, cotton prices, and the exchange of cotton for corn - growing cotton was a much riskier way to feed one's family than growing corn for on-farm consumption. Indeed, almost one-fourth of the farms in the Parker-Gallman sample did not grow cotton at all, and many others grew only small amounts, apparently treating it as a "surplus" crop in the sense suggested here. ${ }^{17}$

This analysis puts a different perspective on the observation that largescale plantation agriculture occurs only with slave labor, never with free labor (I, p. 234). If we reject the notion of a "special advantage" in productivity, then there is nothing paradoxical about the absence of large-scale free-labor farms, because they were not observed anywhere in nineteenthcentury American agriculture. The argument presented here is merely a variant on the classic explanation of the economic basis for slavery: In a world of land abundance and independent, self-sufficient farms, there is no supply of permanent wage labor in agriculture. The universal preference for farm ownership may well have a "nonpecuniary" component, but farmers also valued the economic security which land ownership provided, and they also enjoyed the earnings of the land and the prospect of realizing large capital gains from an increase in land values. For reasons such as these, farms throughout the United States were essentially limited to the family labor force, only occasionally making use of uncertain, hard-to-find, and frequently temporary hired labor. The "economic significance of property rights in man" was to provide an elastic labor supply to the individual farm, allowing an expansion under constant returns to scale, which was not possible in the free states. ${ }^{18}$ If this analysis is correct, then it is inappro-

\footnotetext{
${ }^{17}$ For elaboration on the safety-first model and further documentation on its application to the South, see Kun reuther and Wright, 1974; Wright and Kunreuther, (1975).

${ }^{18}$ This analysis follows closely the more detailed presentation of Fleisig (forthcoming). Fleisig traces the implications for factor proportions and farm scale of a constraint on the labor supply at the farm level, and finds empirical support in census averages. On the universality of the sharp break between family and nonfamily labor, see Parker, 1972, esp. pp. 393398.
} 
priate to compare realized pecuniary incomes between small farms and large slave plantations (i.c., to value outputs at market prices), because most small farmers were intentionally sacrificing expected pecuniary income for security-precisely for the purpose of protecting their property ownership and their status as independent farmers.

\section{The Cotton Boom and the Growth of Southern Incomes}

Perhaps the most important implications of the analysis proposed here concern the explanation for the course of Southern regional progress before and after the Civil War. Several scholars have questioned the sustainability of the high growth rates observed between 1840 and 1860 , on the grounds that these rates were very largely a function of the redistribution of population from east to west. ${ }^{19}$ In Time on the Cross, Fogel and Engerman respond to this criticism by noting that differences in sectoral or subregional growth rates are a perfectly normal feature of economic growth, and that studies of twentieth-century experience also attribute a substantial share of productivity growth to intersectoral shifts. Their discussion may be somewhat misleading in that it fails to distinguish between the general phenomena of sectoral unevenness and responsiveness to change, and the particular phenomenon of a once-for-all contribution to growth from the closing of a disequilibrium "gap" between sectors or regions. Just as sectoral shifts have often been a part of economic development, so also have high growth rates often proved ephemeral when based on a nonrenewable resource or "gap." The citation of the research of Edward Denison seems particularly misplaced, since one of the central themes of Why Growth Rates Differ is precisely the argument that some very high growth rates recently observed should be discounted somewhat, because they rest on the transfer of labor from traditional to modern sectors, and hence cannot be sustained indefinitely. Thus, despite their verbal skills and powers of persuasion, Fogel and Engerman have not really addressed or disposed of their critics' objections that the growth achievement of the South is less substantial than the overall growth rate implies.

The issue of impermanence, however, runs deeper than the question of migration. The more fundamental underpinning of much of this growth is, again, the rapid but essentially temporary growth in world demand for cotton. The reason that regional migration makes such a large contribution to growth between 1840 and 1860 is that per capita income in the West South Central region is more than twice as great as in the South Atlantic and East South Central regions. These high income levels do not represent a more "advanced" state of economic development in the West, but reflect primarily the superior soil and climate of that region in terms of cotton production. Hence the real source of growth was not so much migration as

${ }^{19}$ Parker, 1970, p. 119; Woodman, 1972. 
cotton demand. Correspondingly, the income decline of the Western region between 1860 and 1880 exceeded that of the two Eastern regions by a wide margin.

In addition to the effects of the rapid average annual growth of cotton demand during the late antebellum period, the measured growth rate of per capita income between 1840 and 1860 is probably increased by the particular state of demand during the two census years involved. Econometric estimates of the cotton demand curve indicate, as noted above, that demand was above its trend value in 1859-1860 (i.e., that the price of cotton was above the level "predicted" on the basis of production and trend) by $7.6 \%$ to $15.9 \%$. On a comparable basis, the cotton price for the census year 1839 1840 was between $4.0 \%$ and $11.5 \%$ below its predicted value. Hence, it appears that over and above the rapid average growth of cotton demand, the choice of endpoints imposed by the census data makes $1.7 \%$ per year a trough-to-peak figure, giving an extra upward "tilt" to the Southern growth path. ${ }^{20}$

There is no getting around the fact that incomes earned in cotton were fundamentally governed by demand. But trends in productivity in cotton growing are not irrelevant to regional income growth, because resources released from cotton can be used to produce other outputs. Much of the loss of income between 1860 and 1880 resulted from lower production of noncotton crops, because a larger fraction of Southern resources went into cotton-growing, and self-sufficiency in food was abandoned. The possibilities for alternative crop production were actually quite limited-most of the region had no other cash crop-but the trends in cotton productivity bear close examination anyway, because they at least were subject to the influence of Southerners, which was not true of demand and may not have been true of the choice of crops.

Fogel and Engerman maintain that improvements in the efficiency of management, especially labor management, were "the most important technological advance within the agricultural sector of the South after 1800 " (I, p. 199). They point to the "substantial increase in the average size of slaveholdings" during this period (I, p. 200), a development which, in conjunction with the total-factor-productivity estimates, clearly implies significant productivity growth over time. ${ }^{21}$ In this way Time on the Cross

\footnotetext{
${ }^{20}$ The same cannot be said for the Northern figures. As North states: "The years from 1858 to 1861 present no picture of booming expansion" (North, 1961, p. 255).

${ }^{21}$ Fogel and Engerman do acknowledge briefly that the "changing structure of demand" (my italics) explains the migration of slave labor among states, and they note also that the expansion of scale "coincided" with a "shift from the production of grain and tobacco to cotton, sugar, and rice" (I, pp. 199-200). But the bulk of their discussion deals with the development of managerial skills and techniques, and while it is not specific on the point, it strongly implies that management was becoming increasingly efficient. That they do have an increase in efficiency in mind is acknowledged explicitly at several points (I, p. 93; II, p. 86).
} 
conveys the impression of rapid technical progress and major gains in efficiency; but, remarkably, the book contains little discussion and virtually no evidence on the rate or sources of productivity growth over time. ${ }^{22}$ In fact, there is very little evidence of substantial productivity growth under slavery-other than that associated with the increase in the quantity and quality of cotton land.

The one specific piece of evidence presented by Fogel and Engerman to support a claim of efficiency improvement over time is the slow downward long-run trend in the price of cotton of $0.71 \%$ per year (I, p. 91; II, p. 86). But there is only a casual effort to list the reasons for this rather modest decline. As they note, the list would have to include such items as the "reduction in transportation and other marketing costs, and the relocation of cotton production in the more fertile lands of the New South" (I, p. 93). Surely there is little basis here for a claim of major improvements in productive efficiency over time. To the contrary, it is difficult to see how there could be much room left for the contributions of "scale expansion" and "advancement in the realm of management," when the more obvious developments in location and transport are taken into account.

In an earlier publication, Fogel and Engerman did refer to the productivity estimates of Foust and Swan from the 1850 census, which imply that output per worker grew at $2.9 \%$ per year during the 1850 's. ${ }^{23}$ The authors calculated that this growth was too rapid to be explained by an expansion of acreage and must imply an increase in efficiency. ${ }^{24}$ Unfortunately, the calculation by which this conclusion was reached was erroneous. ${ }^{25}$ Furthermore, the Foust-Swan productivity figures contain a puzzling anomaly: all of the growth is concentrated in the "Alluvial" and "Other New South" regions; the "Old South" showed virtually no gain. This anomaly, and perhaps the entire increase, may be explained in terms of random fluctua-

\footnotetext{
${ }^{22}$ The only exception is a reference to a 1947 U.S. Department of Agriculture study (Miscellaneous Publications No. 630), which offers a completely unsubstantiated figure of $0.79 \%$ per year for the period 1800-1840 (II, p. 86). For what it is worth, all of the productivity gain in this estimate is due to a fall in man hours per acre.

${ }^{23}$ Foust and Swan, 1970, pp. 44-45.

${ }^{24} \mathrm{Fogel}$ and Engerman, 1971, p. 315.

${ }^{23}$ From estimates of factor shares and population growth, Fogel and Engerman computed the implicd rate of growth of cotton acreage under the assumption of constant efficiency. They found that, if there were no change in efficiency, $2.9 \%$ productivity growth implies that land must have increased by 3.4 times between 1850 and $1860(\stackrel{*}{T}=12.1 \%$, not $15.1 \%$ as the footnote reports). They argue that this is an unreasonably large increase in cotton acrcagc. Apparently, however, they erroneously added the 1860 acreage estimate to the 1850 figure to obtain their figure of $19,000,000$ required acres, when they should have subtracted the two. The actual implied acreage expansion is $10,100,000$ acres, which is almost exactly equal to the increase in improved acreage in the seven states during these 10 years $(10,080,000$ acres $)$. This is with no allowance for improvement in average land quality, nor for the random yield fluctuations discussed in the text.
} 
tions in yields around their normal levels, interpreted as deviations from the long-run supply function. As noted above, cotton supply was well above its predicted level in the census year 1860, especially in the New South; by contrast, in the census year 1850 New South output was at or slightly below its predicted level, while aggregate output was betwcen $5.8 \%$ and $19.7 \%$ below. In other words, Old South yields must have been below normal in $1849-1850$, and at or below normal in 1859-1860; New South yields were normal or below in the first year, far above normal in the second. Hence, it appears that virtually all of this alleged "productivity growth" is attributable to the accidental characteristics of the census years, which may even cover up declining productivity in the Old South.

We are left with the conclusion that the primary dynamic force driving the Southern economy in the nineteenth century was the expansion of cotton demand. Discussions of just how "backward" the South was in 1860 are beside the main point, which is the dependent character of the Southern economy, its need for an outside stimulus to maintain continued growth. Viewed in these terms, the slave South should be grouped with those economies which exhibit rapid growth during a period of high external demand for a resource-intensive export, but which do not develop the institutions or acquire the skills needed for sustained growth once this era has passed ${ }^{26}$ Because the cotton boom was not sustained, and could not have been sustained indefinitely, a post-1860 slave South would have suffered many of the development problems actually experienced by the postslavery South. There were many missed opportunities after the war, for the South and for the nation, in terms of racial justice and economic equity. But the best opportunities for basic economic improvement had long since been foreclosed by the patterns of development under slavery.

\section{REFERENCES}

Berry, Thomas S. (1943), Western Prices before 1861. Cambridge: Harvard University Press.

Caves, Richard (1971), "Export-Led Growth and the New Economic History." In Trade, Balance of Payments and Growth: Papers in Honor of C. P. Kindleberger. Amsterdam: North-Holland.

David, Paul, and Temin, Peter (1974), "Slavery: The Progressive Institution?" Journal of Economic History 34 (September).

Davis, Lance E. (1965), "The Investment Market, 1870-1914." Journal of Economic History 25 (September).

Fleisig, Heywood (forthcoming), "Slavery, the Supply of Agricultural Labor, and the Industrialization of the South." Journal of Economic History.

Fogel, Robert, and Engerman, Stanley (1971), "The Economics of Slavery." In Fogel and Engerman, Eds., The Reinterpretation of American Economic History. New York: Harper and Row.

${ }^{28}$ This is essentially the position argued by North (1961, esp. Chap. 10). For a recent review of the literature on cases of this type, see Caves, 1971. 
Fogel, Robert, and Engerman, Stanley (1974), Time on the Cross, Vol. 1, The Economics of American Negro Slavery, Vol. II, Evidence and Methods-A Supplement. Boston: Little, Brown and Co.

Foust, James D., and Swan, Dale E. (1970), "Productivity and Profitability of Antebellum Slave Labor: A Micro Approach." Agricultural History 44 (January).

Kunreuther, Howard, and Wright, Gavin (1974), "Safety-First, Gambling, and the Subsistence Farmer." Fels Center Discussion Paper No. 59, University of Pennsylvania.

Lichtman, Allan J. (1974), "A Benign Institution." The New Republic, July 6, 13.

North, Douglass C. (1961), The Eronomic Growth of the United States 1790-1860. Fnglewood Cliffs, N.J.: Prentice-Hall.

Parker, William N. (1970), "Slavery and Southern Economic Development." Agricultural History 44 (January).

Parker, William N. (1972), "Agriculture." In L. E. Davis, R. A. Easterlin, W. N. Parker et al. . American Economic Growth. New York: Harper and Row.

Phillips, Ulrich B. (1918), American Negro Slavery. New York: D. Appleton and Co.

Ramsdell, Charles W. (1929), "The Natural Limits of Slavery Expansion." Mississippi Valley Historical Review 16 (September).

Ransom, Roger, and Sutch, Richard (1975), "The Impact of the Civil War and of Emancipation on Southern Agriculture." Explorations in Economic History 12 (January).

U.S. Census (1860), United States Bureau of the Census, Eighth, Agriculture of the United States in 1860 . Washington, D.C.

Williamson, Jeffrey G. (1974), Late Nineteenth Century American Economic Development. New York: Cambridge University Press.

Woodman, Harold D. (1972), "Economic History and Economic Theory." Journal of Interdisciplinary History 3 (Autumn).

Wright, Gavin, and Kunreuther, Howard (1975), "Cotton, Corn, and Risk in the Nineteenth Century," Journal of Economic History. (September)

Wright, Gavin (1969), The Economics of Cotton in the Antebellum South. Ph.D. dissertation, Yale University.

Wright, Gavin (1971), “An Econometric Study of Cotton Production and Trade, 1830-1860." Review of Economics and Statistics 53 (May).

Wright, Gavin (1974), "Cotton Competition and the Post-Bellum Recovery of the American South," Journal of Economic History 34 (September). 